\title{
Legal redress of environmental disruption in the United States: The role of courts*
}

Burgeoning public concern about environmental quality has, inevitably, had its impact on the legal system. Laws are being enacted setting quality standards, appropriating money to purchase park lands, subsidizing treatment of pollution, and creating new government regulatory agencies. It is even being recommended by a number of serious legislators that the federal constitution be amended to add a provision guaranteeing to the people an inalienable right to a decent environment.

In all the stir of legislative and political activity, insufficient attention may be given to the courts, where very significant developments are taking place. Environmental problems are not a novelty in American courtrooms. Judges have traditionally abated pollution as a nuisance, at the behest of nearby property owners; and it is quite common for government agencies to obtain judicial enforcement of their orders regulating the use of land, water and air.

During the last few years, however, a rather novel kind of court action has been developing which has important implications not only for legal institutions, but for our whole way of thinking about how to deal with environmental problems. These new lawsuits are particularly characterized by three facts: first, the plaintiffs are private citizens, not public agencies; second, they sue not as property owners nor as protectors of any conventional private interest, but as members of the general public asserting rights they claim simply

* This paper was presented at the "International Symposium on Environmental Disruption in the Modern World: A Challenge to Social Scientists"'. (The symposium, held in Tokyo, March 8-14, 1970, was organized by the Standing Committee on Environmental Disruption of the International Social Science Council.)

(C) 1970 by Joseph L. Sax. No reproduction in any form authorized without special permission of the author.

A volume of conference papers has now appeared under the title Proceedings of International Symposium on Environmental Disruption. A challenge to social scientists, S. Tsuru (ed.). The book is not distributed commercially but can bo obtained at cost from the International Social Science Council. 
as members of the public; and finally, the defendants in these cases are frequently the very governmental agencies which are themselves supposed to be protecting the public interest.

Such cases arise in many contexts. They may be brought against a highway department to challenge the location of a new road; or against a pollution control agency on the ground that it is not enforcing the law adequately. A private industry or utility company may be sued to enjoin its plans for locating a new plant or transmission line right of way.

The subject matter of such cases covers the whole range of environmental issues, from urban air pollution to wilderness management in the high country, from drilling oil under the sea to the location and operations of airports. The real significance of such cases, however, lies in the disillusionment they betoken with the efforts and accomplishments of government agencies which are supposed to be protecting the quality of the environment. For in every situation where lawsuits such as those just described are instituted, there is almost always at least one agency of government which is officially charged with preventing unreasonable environmental disruption.

Such lawsuits are thus indicators of a citizens' revolt against official protectors of the public interest. They are a sign that the victims of environmental disruption want to get back into the process of governing themselves, and are no longer willing to leave their fate in the hands of bureaucratic hirelings who, like mercenary soldiers, develop interests and goals of their own which are by no means necessarily identical to those of their principals.

In the past, reliance on professional regulators went so far that private citizens were excluded even from the opportunity to participate in the process; a whole panoply of legal rules held that the job of protecting the public interest was to be left exclusively to governmental administrators. When a citizen did try to intervene, he was promptly excluded as an interloper, a busybody who should leave the job of regulation to the experts. Thus, for example, it was said that a private citizen had no "standing" to challenge governmental regulation on behalf of the public. In the last few years, however, these restraints have begun to fall away; even the most traditional-minded judges have come to recognize that the private citizen has a legitimate, and at times essential, role to play in the determination and implementation of the public interest. The following quotation is taken from an opinion of the present Chief Justice of the United States, Warren Burger - certainly a traditionalist. The case itself involved an application for a renewal of its license by a radio station. Local citizens and organizations sought to intervene in the proceeding to object to the renewal, and the regulatory agency which handles such matters attempted to exclude the citizens as intermeddlers. To this Judge Burger replied: "The theory that the Commission can always effectively represent the listener interests [...] without the aid and participation of legitimate listener representatives fulfilling the role of private attorneys general is one of those assumptions we collectively try to work with so long as they are reasonably 
adequate. When it becomes clear [...] that it is no longer a valid assumption which stands up under the realities of actual experience, neither we nor the Commission can continue to rely on it [...] We cannot fail to note that the long history of complaints [...] had left the Commission virtually unmoved [...] The renewal application might well have been routinely granted except for the determined and sustained efforts of [the complaining citizens] at no small expense to themselves".

Administrative agencies recoil in shock at the prospect of being taken to court by "mere" citizens. They will be subject to delay, they say, to interference with long established plans, and will have to spend valuable time justifying themselves in a courtroom. Litigation is indeed inconvenient for them; but it is at the same time very revealing. Why, for example, do administrative orders against air and water pollution so often go unenforced for years? Why do public agencies dispose of valuable wetlands for filling by housing developers, when other less ecologically significant uplands are available? Why do road building agencies so often want to take park lands and preserves for their highways? How do industries get permission to take risks which lead to occurrences such as the deplorable oil leakage at Santa Barbara, California?

The answer, often, is that regulatory agencies see these issues from a peculiar perspective all their own. The decision to lease submerged lands for oil drilling off the California coast at Santa Barbara illustrates this problem in a most instructive manner. When the question was raised whether federal lands should be leased, local citizens - despite the great difficulty of obtaining information - were most dubious about the project. As to the problem of spillage, as one Santa Barbara official later recalled, the problem "was discussed many times, but always Interior Department and oil industry officials led us to believe we had nothing to fear. They said they had perfected shutoff devices that were foolproof even in such disasters as a ship running into the platform or an earthquake".

Later events at Santa Barbara demonstrated just how misplaced that confidence was. The distressing part of the story, however, is not merely that those who ought to have known better were wrong - but rather that every effort to open such issues to inquiry was brushed aside or ridiculed because other more powerful forces had already predetermined the leasing question.

When questions were raised about the proposal by concerned citizens, federal officials responded publicly with a letter saying "we feel maximum provision has been made for the local environment and that further delay in lease sale would not be consistent with the national interest". Privately, though, an interagency memorandum was circulated commenting that "the 'heat' has not died down but we can keep trying to alleviate the fears of the people" and noting that pressures were being applied by the oil companies whose equipment "costing millions of dollars" was being held "in anticipation". 
The eagerness of Interior Department officials to get the leasing over with quickly and quietly was made clear in a memorandum written when it was learned that another federal agency was considering holding public hearings at Santa Barbara prior to the leasing. Here is the text of an Interior Department memorandum circulated privately in response to that suggestion: "Discussion centered around 'public interest' aspects in our offshore operations. Outlined what we had done in Santa Barbara and how it appeared to conflict with Corps public hearing [...] Of course, how they handled the public was their business, but we did not have to participate [...] I pointed out that we had chosen not to go the public hearing route [...] That we had tried to warn the [...] District Engineer of the Corps what he faced and we preferred not to stir the natives up any more than possible" (sic).

The reason for the eagerness of the Interior Department to go forward with the leasing was made quite clear later, after the oil spill, when responsible officials were called upon to testify about the decision. The former Secretary of the Interior explained it all quite succinctly. The Bureau of the Budget was "hungry for revenue" and "a Presidential decision had been made about getting more money to help balance the national budget [...] Communications from the budget bureau were indicating to us that we should have a maximum leasing program".

No doubt these considerations were reason enough to persuade the Interior Department. And from their perspective, the choice could hardly have been different. It is not the Secretary of the Interior's job to undermine the President's programs; he is - as we are so often told - a member of the President's team. The question, however, is who was representing the interests of the citizens of Santa Barbara and of the general public who have a stake in that environment? Not the oil companies; not the Interior Department, which had other priorities; and not the Santa Barbara citizens themselves, who never really had an opportunity or the means to participate in the decision making process. They were merely bystanders, passive recipients of publicity-release assurances that all was well.

It was this realization which finally led a prominent Santa Barbara businessman to say: "We are so goddamned frustrated. The whole democratic process seems to be falling apart. Nobody responds to us, and we end up doing things progressively less reasonable [...] Nothing seems to happen except that we lose".

The Santa Barbara case is not unusual; indeed it is typical of a most pervasive and central fact about the administrative process. Regulatory agencies have an interest and perspective of their own which is frequently at odds with that of significant segments of the public whose interest the agency is supposed to be protecting.

Moreover, the limitations of these surrogate agencies have been highlighted as public concern about environmental problems has enlarged and diversified. An agency which has been in the business of selling timber or building roads 
does not easily adapt to new public policies which go beyond mere managerial and technical regulation, and require a broad ranging consideration of environmental consequences. Highway departments do not find it easy to ponder the considerations for not building roads.

These difficulties are not unique to the problems of the environment, but they are being most dramatically illustrated in this area because environmental problems preeminently reflect the demand that the governmental process bring a variety of perspectives to bear upon the resolution of problems. Thus, the elements which peculiarly characterize the administrative process narrow technical expertise, managerial rather than policy orientation, historical association with particular interests, and concern for its own budget and its own programs - tend to lock it into a limited "inside perspective". We need to provide a fresh point of view, an outside perspective.

In a recent case, for example, private citizens challenged a government sale of timber on national forest lands to a private lumber company. The plaintiffs alleged that the area in question should have been reserved as an addition to the national wilderness system. The defendant US Forest Service was adamant in insisting that the tract be committed to timber harvesting and was unwilling to delay its decision until the Congress would - within the next year - have a chance to review the entire area to determine whether a nearby wilderness area should be enlarged to include this tract. Local citizens brought suit in federal court, and the judge asked the questions which any reasonable outsider would find a matter of puzzlement. What was the hurry about cutting in this area, and why could there not be a delay until congressional review was completed?

The case went to trial and it was revealed that the original decision to harvest timber on this tract had been made as early as 1962, several years before the wilderness system was even created by legislation. In pursuance of this decision - also before the wilderness law came into force - the Forest Service had built a road into the area. Roads of this kind are necessary for timber harvesting. Once the investment in a road had been made, the Forest Service was essentially locked into the decision to harvest timber there. Other areas nearby, not alleged by anyone to be suitable for wilderness designation, were appropriate for timber harvesting, but there was no road built elsewhere and the Forest Service was obviously reluctant to "waste" a road it had already built. To save a little money and avoid some inconvenience to plans that had evolved out of their routine bureaucratic machinery, the Forest Service avoided taking the wholly fresh look at the situation which enactment of the 1964 Wilderness Act seemed to require of them. The desires of the forest products industries, with which they regularly worked and with whom they had long standing relations, prevailed over the efforts of other citizen groups concerned about wilderness. This latter group came upon the scene as intermeddlers, upsetting the smooth working bureaucracy.

Citizens have been turning increasingly to the courts because the judiciary 
offers an opportunity to bring a fresh and uncommitted perspective, an outsider's perspective, to environmental problems; and judges are asking questions which all too often are not asked by the agencies charged with the routine job of regulation. Why wouldn't it have been reasonable to wait a little longer, until Congress had a chance to look at this area as wilderness, before depriving it of asserted wilderness qualities by cutting the timber? Why was it necessary to take park land for this highway interchange? Why is an air or water pollution control order not being more rigorously enforced? Why is no one examining the environmental effects of utility company condemnations for rights of ways?

Plainly the rise of citizen initiated litigation is not attributable to any belief that judges are wiser than other officials, or that they should finally determine our environmental policies. Rather, litigation represents an attempt to bring concerned citizens into the decision making process by opening a forum in which there is relative equality of access and an opportunity to get issues out into the open where they can be considered on the merits.

In most cases, citizens seek no more than that the courts provide an opportunity for open debate and public resolution of serious environmental questions, rather than leaving them for quiet disposition within the deep recesses of the administrative process. In the Colorado wilderness case mentioned earlier, for example, the request was essentially for a judicially declared moratorium on timber cutting until the case could be taken to the Congress for its determination.

Frequently, the relief sought from the courts is in essence a "remand" to the legislative process so that controversial decisions, and unresolved conflicts of policy, can be put openly before elected representatives for decision. This technique is pointedly illustrated by a series of recent cases which have arisen in the state of Massachusetts.

Citizens challenged the highway department's decision to take park land for its own use, and the court noted a disturbing insensitivity on the part of the highway agency to the state's concern for the maintenance of public parks. The defendant highway department claimed it had ample authority under a broad statute which authorized it to "improve" the lands of the commonwealth; thus, it said, it could take park land at will, and its decision to do so must be respected by the judiciary. This was too much for the Supreme Judicial Court of Massachusetts. Plainly annoyed by such arrogance, the court responded: "The improvement of public lands contemplated by this section does not include the widening of a State highway. It seems rather that the improvement of public lands which the legislature provided for [...] is to preserve such lands so that they may be enjoyed by the public for recreational purposes". The court held that before the highway department could take park land it had to go to the legislature and obtain specific authorization.

The goal was to deprive the highway agency of ultimate authority over the policy question involved and to force the legislature openly to consider and 
resolve the issue presented by the suit. Technically, the court ruled that the highway department lacked adequate authority to seize park land at will. Essentially, however, the purpose of the lawsuit was to put the issue before the legislature where it would have to be confronted and resolved in the full light of public attention. The court thus ruled: "It is essential to the expression of plain and explicit authority to divert park lands [...] to new and inconsistent uses that there appear in the legislation not only a statement of the new use but a statement or recital showing in some way legislative awareness of the existing public use. In short, the legislation should express not merely the public will for the new use but its willingness to surrender or forego the existing use".

It is with holdings such as this that courts respond to citizen pressures to democratize the decision making process as it affects issues of environmental quality. The effect of such holdings is suggested by a letter which the plaintiffs' attorney wrote, describing the events which followed the court's decision: "The Legislature of Massachusetts had more discussion over the Fowl Meadow, the park land involved in the case, than almost anything else [...] in 1969 [...] After a Herculean effort, the House of Representatives in Massachusetts voted $134-90$ to authorize a feasibility study of a westerly route, such as we have been working for. However, our local highway department brought out its troops in the form of at least six men who spent most of the week in the State House and, after reconsideration, obtained a bill for an opposite route by the narrow score of 109-105. The Senate concurred after removing some amendments and the Governor signed the bill. However, the whole subject of super highway construction [...] has been put in the hands of a sevenman commission which is to report whether any new highways are needed [...] In the meantime, the Governor has stated in public and written us that he will not permit the transfer of the requisite park land".

To be sure, such litigation does not assure that the advocates of any given position will triumph, or that the legislature will necessarily produce a wise resolution. It does, however, help to move questionable environmental decision making into a forum where issues of policy must be made and articulated openly, and where legislators must assess the political consequences of taking one position or another. Measured against a system which has been characterized by its responsiveness to particular and limited perspectives, and by its penchant for quiet resolution of potential conflict (often revealed in the attitude that the less the public knows, the less trouble there will be), judicial intervention of the type described above is a significant step forward.

In an area such as environmental quality, where we struggle so much to determine what our goals should be, it is instructive to recall from time to time the enormous difficulties encountered in getting public agencies to respond to those situations in which there is a substantial consensus about goals; and in which narrow interest groups have learned to manipulate the governmental process to their own advantage, to the dismay and detriment of the domi- 
nant community. All too often the public ${ }_{i}$ is simply ${ }_{i}$ presented with a fait accompli.

Plainly, the deep problems of environmental quality go beyond the ability of any court to manage within the confines of a particular case. No court decision will resolve the issues of population, of the automobile versus intelligent mass transit, or the inclination toward uncontained economic growth. What judicial decisions do, however, is to bring home the costs which these problems impose as they come to rest upon particular communities in specific contexts. The difficulties we have in pricing and managing external effects take on sharply visible contours when a highway location is challenged in each town through which it passes, or when a polluting industry is challenged to justify its conduct in a discrete context. Each such case, then, thrusts back upon the policymakers the requirement that they face up to the cumulative effects of their decisions, and gives those upon whom such external costs are imposed a chance to put a price tag on them in terms of their own discomfort and inconvenience. Wars are fought battle by battle, not in place of a grand strategy, but to effectuate it.

It has been traditional to tell complaining citizens to take their problems to the legislature, or to assume that, ultimately, resort to the ballot box will assure effectuation of the public will. The electoral process, as those who have suddenly awakened to see the bulldozers at work well know, is a very blunt instrument. In the swirling multitude of issues that intervene between periodic elections, it is not easy to cast a ballot which clearly says I disapprove your highway policy, approve your stance on foreign aid and abhor your farm policy. Nor is it very realistic to tell a troubled community to go to Congress and get a law enacted to stop a project which is to go forward within a matter of days or weeks.

We are also asked to have faith that administrative agencies will cure themselves of their traditional narrowness, and hope that legislative mandates ordering them to undertake broader perspectives will bring significant changes. Perhaps these changes will occur; thus far the process has been so slow as to be almost imperceptible. The wilderness case demonstrated that even the best of regulatory agencies - such as the Forest Service - lose their traditional bureaucratic perspectives glacially, despite strong legislative pronouncements. Other agencies such as the US Corps of Engineers continued to state, even in their official public notices, that they concerned themselves only with navigation effects years after they had been subject to the broader requirements of the federal Fish and Wildlife Coordination Act. It is time to recognize that the prospect of external scrutiny, such as the courts are prepared to employ, may itself be the most effective remedy for slothful administrators; and that no one is so likely to seize the needed initiative as the private citizen whose principal interest is that as victim of environmental degradation.

We have a great deal of rethinking to do about our laissez faire attitudes and assumptions about the process of government. Among the very signif- 
icant matters being raised by environmental litigation is whether and to what extent institutions like the judiciary can, and should, intervene to help make that process work more effectively. The technique described above essentially a judicial remand to the legislature - is one device that is now being tested. In essence it says, yes, the citizens should go to the legislature, but a court order may be needed to assure that they can get there in time, and under circumstances which help to assure that their voices will be heard. It may seem ironic that courts are needed to help make the legislative process work effectively; that citizens must come to the least democratic of the branches of government to make democracy work. But that is one of the intriguing questions now being explored under the label of environmental litigation.

\section{REFERENCES}

Opinion of Judge (now Chief Justice) Burger: Office of Communication, United Church of Christ v. Federal Communications Commission, 359 F.2d 994, DC Cir., 1966.

Regarding the Santa Barbara oil leakage: Hearings before the Subcommittee on Air and Water Pollution, US Senate Committee on Public Works, Water pollution - 1969, parts 2, 3, 4, 91st Cong., 1st Sess., 1969.

Colorado Wilderness case: Parker v. United States, 309 F. Supp. 593 (D. Colorado, 1970).

Massachusetts cases: Sacco v. Department of Public Works, 352 Mass. 670, 227 N.E.2d 478 (1967); Robbins v. Department of Public Works, 244 N.E.2d 577 (1969).

General reference: J. Sax, "The public trust doctrine in natural resource law: Effective judicial intervention", Michigan law review 68 (471), January 1970.

Joseph L. Sax, Professor of Law at the University of Michigan, Ann Arbor, has just completed a book entitled Defending the environment, to be published by Knopf later this year. Among his recent publications: Water law, planning and policy (1968); "Public rights in public resources: The citizen's role in conservation and development", in: C. W. Johnson and S. H. Lewis (eds.), Contemporary developments in water law (1970). 